\title{
Plan de compromiso ambiental: Alojamientos turísticos sustentables
}

\author{
L. Pellegero, G. Torres y J. Cédola \\ Programa "Alojamientos Turísticos Sustentables" de la Dirección Provincial de desarrollo sostenible y cambio climático del \\ Organismo Provincial para el Desarrollo Sostenible. \\ E-mail: ats@opds.gba.gov.ar; ats.buenosaires@gmail.com
}

El objetivo del PCA es promover la conservación del ambiente estimulando el uso eficiente de la energía, el agua, las materias primas y el buen manejo de los residuos (generación y separación). Ponderando a productos 0 servicios e informando al usuario 0 consumidor mediante la responsabilidad ambiental asumida por el productor de la actividad y valorando un mejor desempeño en la temática ambiental. El PCA es aplicable a: ATS/ Balnearios/ Campings/ Clubs/ Restaurants.

Como estrategia de gestión se promueve el concepto de sustentabilidad en el desarrollo local, preservando los ecosistemas y sus funciones e incentivando el avance económico de la Provincia mediante un equilibrio continuo, conservando, preservando, protegiendo y disfrutando el ambiente en sus tres dimensiones ambiental, social y económica.

\section{PCA- Alojamientos Turísticos Sustentables}

Con el fin de incorporar la sustentabilidad en el turismo, el Organismo Provincial para el Desarrollo Sostenible (OPDS) crea el Programa de Alojamientos Turísticos Sustentables (ATS) Resol.75/14, que trabaja en forma conjunta con la Subsecretaría de Turismo de la Provincia de Buenos Aires. El Programa ATS incentiva a los prestadores de servicios turísticos a realizar un manejo adecuado en el uso de los recursos promoviendo su ahorro y utilización eficiente, obteniendo una Distinción de acuerdo a las practicas que realizan y que les permite generar una ventaja competitiva y dentro del mercado turístico nacional e internacional. Parámetros de sustentabilidad que se evalúan
- Entorno (Natural y cultural, Socioeconómico y Arquitectura sustentable).

- Gestión del recurso agua.

- Gestión del recurso energía.

- Política de compras y consumo de productos.

- Manejo de los Residuos Sólidos Urbanos.

- Comunicación y participación.

Los parámetros de sustentabilidad que se evalúan, están en sintonía con algunos de los Objetivos de Desarrollo Sostenible (ODS), fijados por Naciones Unidas para sus estados miembro.

\section{Condiciones para obtener la DISTINCIÓN ATS}

- Estar inscripto en el Registro Provincial de Hoteles y Afines.

- Asistir al Taller de Capacitación dictado por el equipo técnico que integra el programa.

- Luego los técnicos de ATS evalúan el establecimiento con el formulario de distinción y de acuerdo con lo relevado in situ se determinará el Nivel de Compromiso Ambiental. (Incipiente, Experimentado, Experimentado Superior y Experto).

- La Distinción ATS es voluntaria y gratuita, con una validez de 2 (dos) años.

- Los alojamientos podrán exhibir la distinción de "Alojamiento Turístico Sustentable", para acreditar las prácticas que realizan en su actividad para el cuidado de los recursos.

Palabras claves: sustentabilidad; alojamientos turísticos; compromiso ambiental; plan de compromiso 